\title{
Pusat Pelatihan Nasional Atlet Paralimpik Dengan Penekanan Aksesbilitas Arsitektur Di Karanganyar
}

\author{
Erwin Herlian, Titis Srimuda Pitana, Tri Joko Daryanto \\ Program Studi Arsitektur \\ Universitas Sebelas Maret Surakarta \\ Email: herlian.erwin@gmail.com
}

\begin{abstract}
Indonesia is one country that has great potential in the Paralympic Olympic event. But unfortunately, the potential and achievements are not supported by means of adequate training of Paralympic athletes. Three importants constraints that affect Paralympic athletes are training, a gym and dorm athletes are far apart, the existing sports facilities are public facilities that are less facilitate Paralympic athletes, as well as the city of Solo that it is not possible to accommodate Paralympic athletes training activities. As a problem-solving strategies, takes planning a national training center that can accommodate the needs of Paralympic athletes to improve athletic ability. The training center emphasizes on the design of the facility is accessible for users, especially the Paralympic athletes. Karanganyar selected as the location of the training center because it meets the criteria of the training center. The formulation of the problem in this design is to realize the concept and design of the National Training Center Paralympic Athletes in Karanganyar with Emphasis Architectural Accessibility. Thus it can be formulated National Training Centre planning objectives is to improve and develop the ability of Paralympic athletes in the international arena by emphasizing design accessible to users. The method is carried out to determine the settlement of the problem is through observation at a boarding, training facilities, and the needs of Paralympic athletes and NPC of Indonesia (National Paralympic Committee of Indonesia). Planning national training centers should emphasize the accessibility of architecture in the design of buildings and facilities that are accessible to users. The principle of accessibility architecture is emphasized that security, safety, usability, and independence. Application of these principles appear in the planning design that uses the ramp in all its circulation both inside and in the curved building, the layout of the room and the furniture, the corridors of the building, parking access, handrail, door with universal design, as well as signs and alarms that apply to building national training center. The division of the building into several mass and circulation that connect a response from the existing contours of the site and to emphasize the accessibility of the architectural design.
\end{abstract}

Keywords: Accessibility Architecture, Paralympic Athletes, Karanganyar, National Training Center

\section{PENDAHULUAN}

"Pusat Pelatihan Nasional Atlet Paralimpik di Karanganyar dengan Penekanan Aksesibilitas Arsitektur" merupakan sebuah judul dari kegiatan perencanaan dan perancangan tugas akhir ini. Fasilitas ini merupakan pusat atau tempat yang paling utama (Wibowo, 2002) untuk melakukan latihan atau kegiatan yang sistematis dari berlatih atau bekerja yang dilakukan secara berulang (Harsono, 1988:101) yang memiliki ruang lingkup nasional atau meliputi seluruh bangsa (Wibowo, 2002). Fasilitas tersebut ditujukan untuk mewadahi atlet paralimpik terutama yang mengikuti perlombaan atau pertandingan (Wibowo, 2002) dalam ajang olahraga untuk atlet berkebutuhan khusus (Paralimpik). Karanganyar merupakan lokasi yang direncakan untuk pusat pelatihan nasional atlet paralimpik ini. Fasilitas pusat pelatihan ini menerapkan kemudahan yang disediakan bagi penyandang cacat guna mewujudkan kesamaan kesempatan dalam segala aspek kehidupan dan penghidupan (Aksesibilitas dalam Undang-Undang No. 4 Tahun 1997).

Indonesia merupakan salah satu negara yang memiliki potensi besar di ajang 
olimpiade paralimpik atau ajang olahraga bagi atlet penyandang disabilitas. Dalam ajang Asean Para Games, Indonesia pernah menjadi juara kedua pada tahun 2012 dan juara umum pada tahun 2014. Sedangkan dalam ajang Paralimpiade, Indonesia berhasil meraih medali perunggu di cabor tenis meja. Namun sayangnya prestasi tersebut tidak didukung oleh sarana pelatihan atlet yang memadai.

Pusat pelatihan yang ada saat ini memiliki tiga kendala yang mempengaruhi latihan para atlet paralimpik. Kendala yang pertama, hampir semua tempat latihan dan asrama atlet terpisah jaun antara satu dengan yang lain. Kedua, fasilitas olahraga yang ada saat ini merupakan fasilitas umum yang kurang memfasilitasi pengguna yang difabel. Serta ketiga, kondisi Kota Solo sebagai lokasi pusat pelatihan saat ini sudah penuh dan tidak memungkinkan untuk mewadahi kegiatan dari para atlet paralimpik.

Pusat pelatihan olahraga memiliki beberapa kriteria penting yang mempengaruhi program latihan atlet. Kriteria-kriteri tersebut meliputi suhu latihan antara $20^{\circ}-24^{\circ} \mathrm{C}$, letak pelatihan yang tidak dekat dengan keramaian kota, serta kondisi lingkungan yang alami untuk mendukung proses latihan atlet. Karanganyar dipilih sebagai lokasi pusat pelatihan dikarenakan Karanganyar memenuhi kriteria-kriteria yang ada. Selain itu, Karanganyar memiliki akses yang mudah dan tidak jauh dari Kota Solo, mengingat Kota Solo sebagai tempat diselenggarakannya perlombaan paralimpik.

Aksesibilitas merupakan faktor penting bagi orang yang menyandang disablitas, hal ini dikarenakan mereka membutuhkan sirkulasi khusus yang dapat mereka akses dengan aman, mudah, dan mandiri. Penekanan Aksesibilitas Arsitektur sangat diperlukan dalam Pusat Pelatihan Nasional ini karena selain kebutuhan dari atlet paralimpik, juga dikarenakan kontur dari lahan yang tidak rata dan masih alami.

Pusat Pelatihan Nasional ini memiliki peran penting terhadap perkembangan atlet paralimpik di Indonesia. Permasalahan tersebut dapat diselesaikan dengan mempertimbangkan kegiatan yang dilakukan oleh atlet dalam berlatih, mulai dari kegiatan olahraga maupun kegiatan pendukung di luar olahraga. Kegiatan-kegiatan tersebut saling berhubungan dan bermanfaat satu sama lain.
Pusat Pelatihan Nasional Atlet Paralimpik di Karanganyar dengan penekanan Aksesibiltias Arsitektur ini diharapkan dapat meningkatkan potensi dan prestasi dari atlet paralimpik di Indonesia, baik di kejuaraan tingkat Paralimpiade, Asean Para Games, dan kompetisi nasional.

\section{METODE.}

\subsection{Macam dan Teknik Pengumpulan Data}

1. Data Pusat Pelatihan: didapat melalui data instansional pemerintah kota dan data dari NPC Indonesia (National Paralympic Committee of Indonesia), serta melalui situs dan artikel terkait.

2. Data Atlet Paralimpik: didapat melalui data dari NPC Indonesia dan wawancara langsung dengan atlet paralimpik.

3. Kondisi Fasilitas Olahraga di Kota Solo: didapat dengan observasi langsung ke tempat latihan atlet paralimpik saat ini. Data lain didapat dari data NPC Indonesia serta dari artikel terkait.

4. Standar Pusat Pelatihan Internasional: beberapa data didapat dari situs resmi NPC di dunia (Paralimpiade serta Asean Para Games).

5. Preseden Pusat Pelatihan: data didapat dari situs serta artikel terkait dengan pusat pelatihan atlet paralimpik.

\subsection{Analisis Perencanaan dan Perancangan}

Proses analisis menggunakan pengolahan data dari data yang telah dikumpulkan. Analisis perencanaan dilakukan dengan mengidentifikasi permasalahan pada objek pengamatan yang kemudian dikaji dengan data literatur dan isu terkini sebagai upaya penyelesaian masalah.

Acuan yang digunakan dalam penyelesaian permasalahan yaitu dengan menekankan prinsip Aksesibiltias Arsitektur ke dalam bangunan maupun lingkungan bangunan. Hasil proses analisis tersebut merupakan bahan perancangan transformasi desain pusat pelatihan nasional atlet paralimpik yang akan direncanakan. 
Analisis perencanaan dilakukan dengan mengidentifikasi masalah yang terdapat pada Pusat Pelatihan Nasional Atlet Paralimpik dengan menekankan prinsip Aksesibilitas Arsitektur. Penyelesaian tersebut juga dilakukan dengan menggabungkan kebutuhan pusat pelatihan, Aksesibilitas Arsitektur, serta dengan standar pusat pelatihan atlet paralimpik di dunia sesuai dengan kejuaraan yang ada.

Prinsip Aksesibilitas Arsitektur yang diterapkan meliputi aspek kegunaan, keselamatan, kemudahan, serta kemandirian.

\subsection{Transformasi Desain}

Proses transformasi desain secara umum mengacu pada empat prinsip Aksesibilitas Arsitektur, yaitu keamanan, kenyamanan, kemandirian, serta kemudahan. Proses transformasi meliputi penerjemahan hasil analisis perencanaan dan perancangan menjadi desain Pusat Pelatihan Nasional.

Proses transformasi diawali dengan penentuan kebutuhan ruang dan kegiatan di dalam pusat pelatihan nasional. Setelah diperoleh kebutuhan ruang dan kegiatan, maka akan ditentukan gubahan massa yang dibutuhkan di dalam pusat pelatihan nasional. Pengolahan gubahan massa juga mengacu pada prinsip Aksesibilitas Arsitektur dengan mewujudkan massa dan lingkungan yang aman, nyaman, mudah, dan mandiri ketikan digunakan oleh penggunanya, terutama atlet paralimpik.

\section{ANALISIS}

\subsection{Analisis Peruangan}

Analisis peruangan diperoleh berdasarkan analisis pelaku dan kegiatan. Peruangan yang direncanakan sesuai dengan fungsi dan kebutuhan dari pelaku dan kegiatannya. Peruangan-peruangan tersebut terbagi menjadi beberapa kelompok sesuai dengan pelaku dan kegiatannya (Tabel 1).

Tabel 1.Kebutuhan Ruang

\begin{tabular}{|l|l|l|}
\hline \multicolumn{1}{|c|}{ PELAKU } & \multicolumn{1}{c|}{ KEGIATAN } & PERUANGAN \\
\hline $\begin{array}{l}\text { Atlet } \\
\text { Paralimpik }\end{array}$ & $\begin{array}{l}\text { Kegiatan asrama } \\
\text { Kegiatan } \\
\text { terprogram }\end{array}$ & Asrama \\
& $\begin{array}{l}\text { Makan bersama } \\
\text { Lapangan olahraga } \\
\end{array}$ & $\begin{array}{l}\text { Ruang makan } \\
\text { bersama }\end{array}$ \\
& Diskusi & Ruang kelas \\
& Kesehatan & Perpustakaan \\
\hline
\end{tabular}

\begin{tabular}{|c|c|c|}
\hline & $\begin{array}{l}\text { Berkumpul } \\
\text { Beribadah } \\
\text { Metabolisme } \\
\text { Kreatif mandiri }\end{array}$ & $\begin{array}{l}\text { Poliklinik } \\
\text { Hall } \\
\text { Masjid } \\
\text { Servis } \\
\text { Ruang pameran }\end{array}$ \\
\hline Pelatih & $\begin{array}{l}\text { Kegiatan pribadi } \\
\text { Kegiatan } \\
\text { terprogram } \\
\text { Makan bersama } \\
\text { Akademik } \\
\text { Diskusi } \\
\text { Kerja } \\
\text { Berkumpul } \\
\text { Beribadah } \\
\text { Metabolisme } \\
\text { Kreatif mandiri }\end{array}$ & $\begin{array}{l}\text { Tempat penginapan } \\
\text { Lapangan olahraga } \\
\text { Ruang makan } \\
\text { bersama } \\
\text { Ruang kelas } \\
\text { Perpustakaan } \\
\text { R. Pelatih } \\
\text { Hall } \\
\text { Masjid } \\
\text { Servis } \\
\text { Ruang pameran }\end{array}$ \\
\hline Ofisial Tim & $\begin{array}{l}\text { Kegiatan pribadi } \\
\text { Kegiatan } \\
\text { terprogram } \\
\text { Makan bersama } \\
\text { Akademik } \\
\text { Diskusi } \\
\text { Kerja } \\
\text { Berkumpul } \\
\text { Beribadah } \\
\text { Metabolisme } \\
\end{array}$ & $\begin{array}{l}\text { Tempat penginapan } \\
\text { Lapangan olahraga } \\
\text { Ruang makan } \\
\text { bersama } \\
\text { Ruang kelas } \\
\text { Perpustakaan } \\
\text { Poliklinik } \\
\text { Hall } \\
\text { Masjid } \\
\text { Servis }\end{array}$ \\
\hline Pengelola & $\begin{array}{l}\text { Kegiatan pribadi } \\
\text { Kegiatan pusat } \\
\text { Kerja } \\
\text { Front desk } \\
\text { Berkumpul } \\
\text { Beribadah } \\
\text { Parkir } \\
\text { Penyimpanan } \\
\text { Memasak } \\
\text { Metabolisme } \\
\text { Kreatif mandiri }\end{array}$ & $\begin{array}{l}\text { Tempat penginapan } \\
\text { Kantor pengelola } \\
\text { R. Bidang } \\
\text { R. Informasi } \\
\text { Hall } \\
\text { Masjid } \\
\text { Garasi } \\
\text { Gudang } \\
\text { Dapur } \\
\text { Servis } \\
\text { Ruang pameran }\end{array}$ \\
\hline Pengunjung & $\begin{array}{l}\text { Parkir } \\
\text { Front desk } \\
\text { Diskusi } \\
\text { Berkumpul } \\
\text { Kegiatan } \\
\text { olahraga } \\
\text { Kegiatan } \\
\text { pameran } \\
\text { Kesehatan } \\
\text { Beribadah } \\
\text { Metabolisme } \\
\end{array}$ & $\begin{array}{l}\text { Parkiran } \\
\text { R. Informasi } \\
\text { Perpustakaan } \\
\text { Hall } \\
\text { Lapangan olahraga } \\
\text { Ruang pameran } \\
\text { Poliklinik } \\
\text { Masjid } \\
\text { Servis }\end{array}$ \\
\hline
\end{tabular}

\subsection{Analisis Lokasi}

Pemilihan tapak disesuaikan dengan kriteria-kriteria dari lokasi untuk Pusat Pelatihan Nasional untuk menunjang kagiatan yang ada di dalamnya.

1. Tujuan

2. Mendapatkan alternatif lokasi yang akan dipilih sebagai lokasi dari pusat pelatihan nasional atlet paralimpik di Karanganyar.

3. Dasar pertimbangan:

Pertimbangan tapak meliputi ukuran tapak yang cukup luas, memiliki akses yang 
mudah dari Kota Solo, memiliki suhu antara $20^{\circ}-24^{\circ} \mathrm{C}$, memiliki aksesibilitas yang mudah untuk kendaraan bermotor, serta tapak tidak berdekatan secara langsung dengan pemukiman penduduk. Kriteria-kriteria tersebut menjadi pertimbangan penting dalam memilih tapak.

\subsection{Analisis Pencapaian}

Pencapaian ke dalam bangunan harus mudah diakses, mudah dilihat dan memiliki sirkulasi yang aman. Hal ini akan menstimulus orang untuk masuk dalam area bangunan.

1. Tujuan: menentukan main entrane, menentukan service entrance.

2. Dasar Pertimbangan: kemudahan akses dari masuk hingga keluar tapak, sirkulasi tapak yang aksesibel bagi penggunanya, arus kendaraan umum dan potensi jalan utama maupun jalan lingkungan, tingkat keamanan, kemudahan, keselamtan, dan kemandirian pengguna.

3. Proses analisis

Main Entrance (ME)

Diakses langsung dari jalan utama dengan mempertimbangkan sirkulasi kendaraan dan pejalan kaku, serta drop off dari pengunjung untuk masuk ke dalam lingkungan bangunan.

Side Entrance (SE)

Membantu sirkulasi terutama untuk pengunjung dengan tidak mengganggu keberadaan dari ME, memiliki jalur menuju ke jalan utama sebagai pintu keluar (Gambar 1).

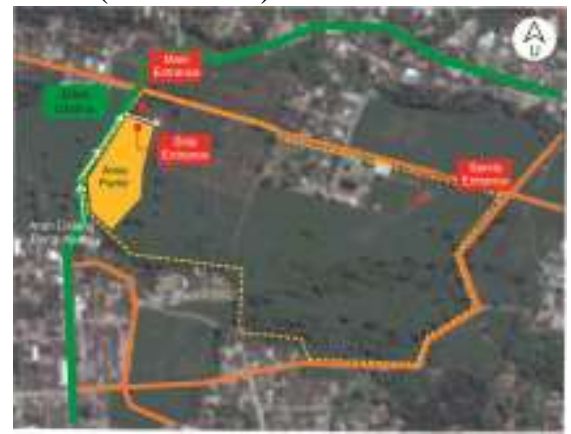

Gambar 1. Analisis Pencapaian

\subsection{Analisis Pemintakatan}

Pemintakatan berfungsi untuk mengelompokkan jenis kegiatan untuk memudahkan pengguna dalam mengakses antar bagian satu sama lain (Gambar 2).
1. Tujuan: Menentukan mintakat berdasarkan sifat kegiatan, kelompok ruang, dan keadaan pada tapak.

2. Dasar pertimbangan: analisis peruangan dan analisis pengolahan tapak.

3. Proses analisis: persyaratan ruang, berdasarkan kelompok kegiatan dan analisis pengolahan tapak.

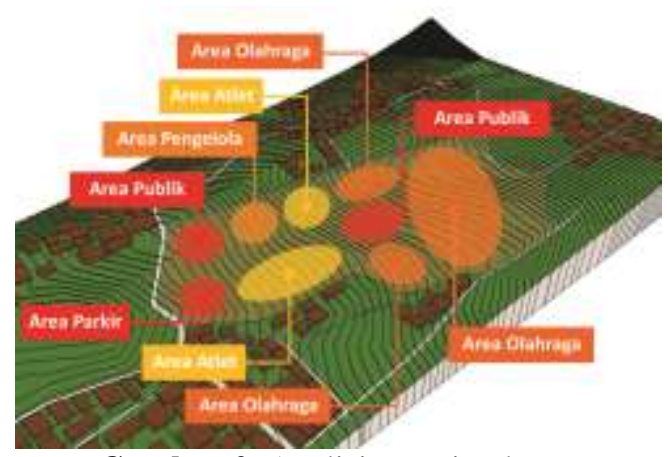

Gambar 2. Analisis Pemintakatan

\subsection{Analisis Bentuk dan Tampilan Bangunan}

\subsubsection{Analisis Bentuk Massa}

Pusat Pelatihan Nasional memiliki massa bangunan yang besar, seperti asrama atlet, gedung olahraga, gedung goalball, serta kolam renang. Setiap bangunan memiliki fungsi yang lebih dari satu, sehingga setiap bangunan harus dapat mewadahi semua kegiatan yang ada di dalamnya. Setiap bangunan memiliki bentuk massa yang berbeda-beda sesuai dengan fungsinya. Bangunan olahraga memiliki bentuk yang dinamis, yaitu kombinasi dari bentuk lingkaran dan sudut dengan olahan pada bagian sisinya (Gambar 3).
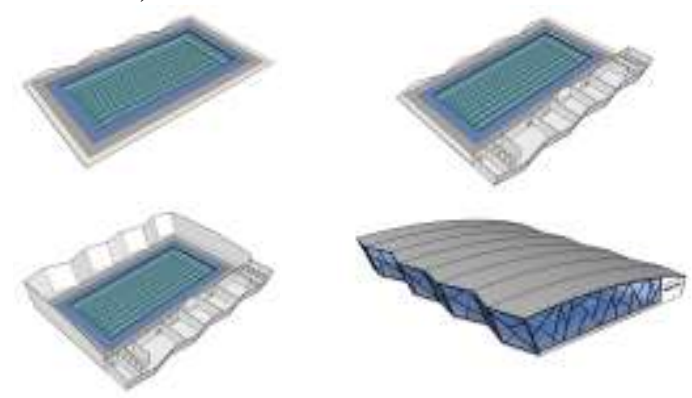

Gambar 3. Transformasi Massa Kolam Renang

Pada bangunan dengan fungsi lain, mengaplikasikan bentuk atap yang berbeda 
dengan atap bangunan olahraga. Hal ini bertujuan untuk membedakan bangunan berdasarkan fungsinya. Bentuk atap ini mengalami kelengkungan karena merespon kontur yang ada pada tapak (Gambar 4). Selain itu, modul massanya pun berbeda-beda sesuai dengan kebutuhan kegiatannya (Gambar 5).

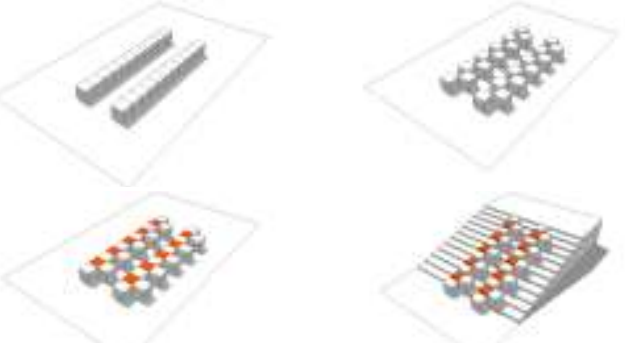

Gambar 4. Transformasi Massa Asrama Atlet Paralimpik.

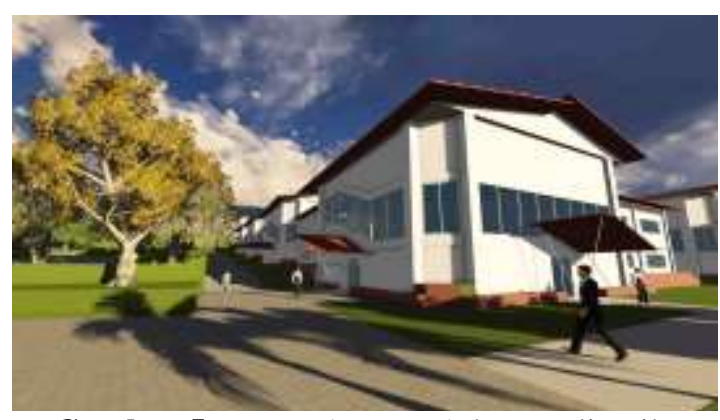

Gambar 5. Massa Asrama Atlet Paralimpik.

\subsubsection{Tampilan Bangunan}

Tampilan bangunan pada massa bangunan olahraga dan bangunan lainnya harus mendukung fungsi yang ada di dalamnya dan penekanan Aksesibilitas Arsitekturnya. Dasar pertimbangan pemilihan tampilan yaitu aspek estetika, jalur masuk cahaya matahari, sirkulasi angin dan udara, akses view keluar ruangan, aspek kenyamanan di dalam ruang, serta aspek aksesibilitas di dalam ruangan. Berdasarkan pertimbangan tersebut, fasad bangunan menerapkan aplikasi material kaca dan atap bentang lebar. Material kaca banyak diterapkan pada sisi bangunan untuk mengoptimalkan pencahayaan alami di dalam ruangan. Hal ini juga bertujuan untuk menambah kesan terbuka di dalam bangunan sehingga penggunanya akan lebih nyaman menggunakannya (Gambar 6).

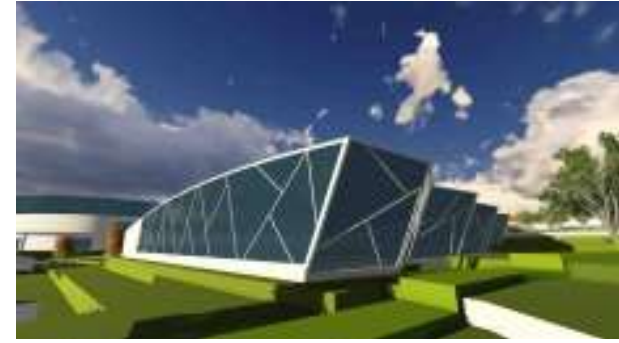

Gambar 6. Aplikasi Material Kaca.

Selain itu, atap bentang lebar diaplikasikan pada bangunan olahraga dan bangunan publik. Hal ini dikarenakan kebutuhan fungsi di dalam ruangan yang membutuhkan ruang yang luas dan meminimalisir dinding (Gambar 7).

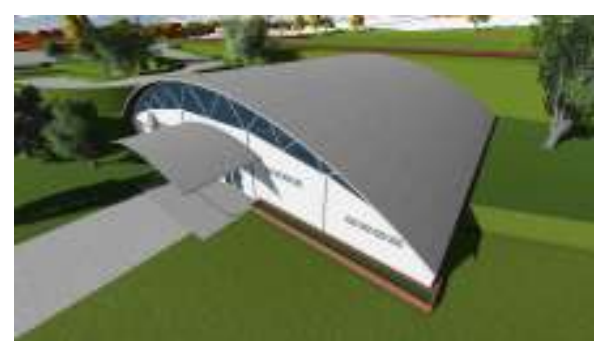

Gambar 7. Aplikasi Atap Bentang Lebar.

\subsection{Analisis Sirkulasi}

Sirkulasi menghubungkan antar massa bangunan dan fasilitas-fasilitas di dalam pusat pelatihan nasional. Sirkulasi menekankan pada prinsip aksesibilitas dan dibagi menjadi 3 macam, yaitu untuk atlet, pengelola, dan pengunjung (Gambar 8).

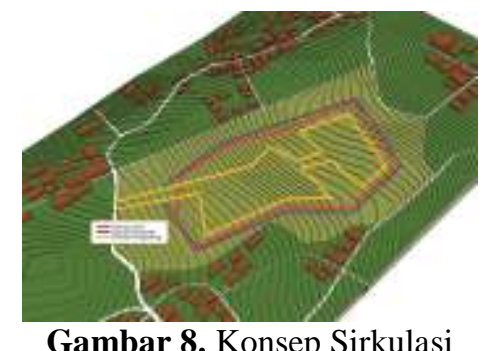

Jalur sirkulasi antar bangunan dan di dalam bangunan dilengkapi dengan jalur pemandu. Jalur pemandu tersebut meliputi sebagai berikut.

1. Koridor: Memiliki ukuran yang sesuai untuk pergerakan kursi roda dengan bantuan rabaan di pembatas sampingnya.

2. Ram: Memiliki kemiringan yang tidak lebih dari $7^{\circ}$ dengan panjang mendatar tidak lebih dari $900 \mathrm{~cm}$. Lebar minimum 
ram adalah $95 \mathrm{~cm}$ (tanpa tepi pengaman) dan $120 \mathrm{~cm}$ (dengan tepi pengaman).

3. Akses Parkir: Memiliki jarak yang dekat dengan pintu utama dan dapat diakses dengan aman dan nyaman. Akses parkir juga dilengkapi dengan perbedaan warna dan tekstur pada lantainya, serta signage pada area parkirnya.

4. Pedestrian: Dapat diakses oleh semua pejalan kaki, termasuk yang memiliki keterbatasan fisik, dengan aman, mudah, dan nyaman (Gambar 9).

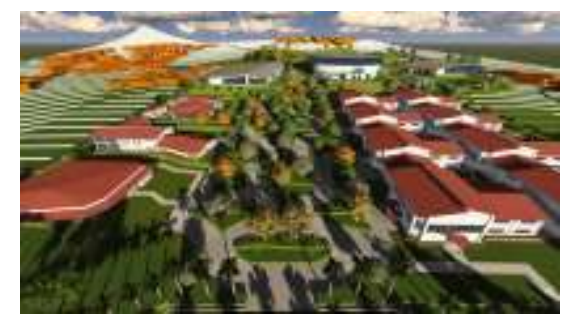

Gambar 9. Konsep Pedestrian

\subsection{Analisis Struktur}

\subsubsection{Sub Structure}

Bangunan di dalam pusat pelatihan nasional oleh bangunan olahraga, hal ini mengakibatkan bangunan tersebut memerlukan permukaan yang rata dengan bentang yang cukup lebar. Oleh karena itu, pada struktur pondasi pada bangunan ini menggunakan pondasi footplate. Pondasi tersebut diaplikasikan dengan menggunakan cut and fill sebelumnya, agar diperoleh kontur yang rata pada tapak. Sedangkan untuk bangunan untuk fungsi lainnya menggunakan pondasi menerus.

\subsubsection{Super Structure}

Pada bangunan olahraga menggunakan sistem kolom dan balok beton dengan rangka untuk membentuk struktur melengkung. Struktur melengkung tersebut akanmenggunakan batu bata ringan untuk mereduksi suara yang ditimbulkan dari dalam bangunan. Sedangkan untuk bangunan bukan olahraga menggunakan beton dan material pembentuk dinding menggunakan batu bata ringan dengan bentuk yang menyesuaikan fungsinya.

\subsubsection{Upper Structure}

Struktur atap bangunan olahraga menggunakan struktur bentang lebar yang menghilangkan kolom di tengahnya. Struktur bangunan bentang lebar tersebut meliputi struktur lipat dan struktur cangkang. Struktur tersebut memiliki nilai estetika tersendiri selain dari fungsinya. Sedangkan untuk bangunan yang bukan olahraga menggunakan struktur atap berupa rangka atap baja. Hal ini bertujuan untuk membedakan fugnsi bangunan antara bangunan olahraga dan bangunan yang lain.

\subsection{Analisis Material Jalur Sirkulasi \\ 3.8.1 Pegangan Tangan (Handrail)}

Atlet paralimpik menggunakan pegangan tangan sebagai pemandu ataupun pembantu keseimbangan mereka. Pegangan tangan ditempatkan pada ketinggian yang aman dan nyaman. Untuk meningkatkan kemudahan pengguna dilakukan dengan memasukkan kontras warna dan keseragaman.

\subsubsection{Perabot}

Perabot merupakan segala perlengkapan dan peralatan pada bangunan serta barangbarang berupa furniture di dalam bangunan pusat pelatihan nasional.

\subsubsection{Pintu yang universal design}

Pintu untuk masuk dan keluar bangunan atau halaman yang mengakomodasi kebutuhan bagi atlet paralimpik.

\subsubsection{Rambu dan Alarm}

Berupa tanda-tanda yang bersifat verbal, visual, serta yang dapat diraba atau dirasa. Rambu dan alarm ini bertujuan untuk membantu penyandang disabilitas dalam mengakses semua ruang dan fasilitas di pusat pelatihan nasional.

\subsubsection{Pedestrian}

Material yang digunakan untuk blok pengarah memiliki kesamaan dengan material yang digunakan untuk blok pemandu. Kedua material tersebut hanya dibedakan oleh tekstur yang melambangkan fungsinya.

\subsection{Analisis Utilitas}

\subsubsection{Utilitas Instalasi Listrik}

Pusat Pelatihan Nasional yang direncanakan menggunakan jaringan listik PLN yang terdapat di sekitar lokasi. Hal ini didukung dengan letak tapak yang tidak jauh dari pemukman warga. Untuk mengantisipasi pemadaman listrik dari PLN selama kegiatan, maka akan disediakan generator sebagai sumber alternatif listrik yang mampu mendukung suplai listrik untuk seluruh bangunan. 


\subsubsection{Utilitas Sistem Air Bersih}

Pusat Pelatihan Nasional menggunakan PDAM dari lingkungan sekitar dan membuat sumur pompa sendiri. Sumur pompa nantinya akan ditampung ke dalam bak tampung air bersih yang akan didistribusikan menggunakan sistem gravitasi. Sedangkan untuk penyediaan sistem air bersih untuk kolam renang menggunakan dua sistem yaitu sistem sirkulasi otomatis dan manual.

\subsubsection{Utilitas Jaringan Air Kotor}

Jaringan air kotor meliputi limbah yang dihasilkan dari setiap massa di pusat pelatihan nasional. Sedangkan jaringan drainase air hujan meliputi pengolahan air hujan pada lingkungan. Analisis jaringan air kotor dan drainase air hujan meliputi sebagai berikut.

1. Jaringan kotor dari setiap massa akan dialirkan keluar bangunan menuju bak air kotor, lalu dialirkan ke bak kontrol, bak lemak, dan septictank yang kemudian dialirkan menuju ke sumur peresapan.

2. Jaringan drainase air hujan akan dikumpulkan di bak khusus penampungan air hujan yang akan digunakan untuk menyiram tanaman atau flush toilet.

\subsubsection{Utilitas Pencegahan Kebakaran}

Pada bangunan tertutup membutuhkan akses untuk mobil pemadam kebakaran masuk untuk pemadaman kebakaran. Sedangkan pada bangunan terbuka memiliki kemudahan dalam pemadaman kebakaran. Selain itu, pada lingkungan bangungan akan direncanakan titik-titik evakuasi dan jalur evakuasi darurat menuju keluar bangunan.

\section{KESIMPULAN (KONSEP DESAIN)}

Konsep rancangan Pusat Pelatihan Nasional mengacu pada penekanan Aksesibilitas Arsitektur yang membantu pengguna dalam menggunakan fasilitas yang diberikan dengan aman, nyaman, mudah, dan mandiri. Prinsip aksesibilitas yang diterapkan dalam pusat pelatihan meliputi kemudahan, keamanan, kemandirian, dan keselamatan.

Dari hasil analisa serta hasil korelasi dari beberapa data di atas, maka diperoleh hasil berupa rancangan Pusat Pelatihan Nasional Atlet Paralimpik di Karanganyar dengan Penekanan Aksesibilitas Arsitektur sebagai berikut.
Lokasi

: Desa Kemuning, Kec. Ngargoyoso,

Kab.

Karanganyar

Luas Lahan $\quad: 132.600 \mathrm{~m}^{2}$

Luas Bangunan : $67.487 \mathrm{~m}^{2}$

Daya Tampung : 350 orang

Kegiatan : Pusat Pelatihan Atlet Paralimpik

Sebagai sebuah pusat pelatihan untuk olahraga atlet paralimpik, Pusat Pelatihan Nasional ini difungsikan untuk memenuhi kebutuhan atlet paralimpik dalam berlatih meningkatkan fisik dan kemampuan mereka. Lokasi pusat pelatihan nasional dipilih beberapa kriteria yang diantaranya memiliki jarak yang dekat dengan Kota Solo. Penekanan Aksesibilitas Arsitektur yang diterapkan pada perencanaan dan perancangan Pusat Pelatihan Nasional ini bertujuan untuk memenuhi kebutuhan dan membantu atlet paralimpik dalam berkegiatan di dalamnya (Gambar 10).

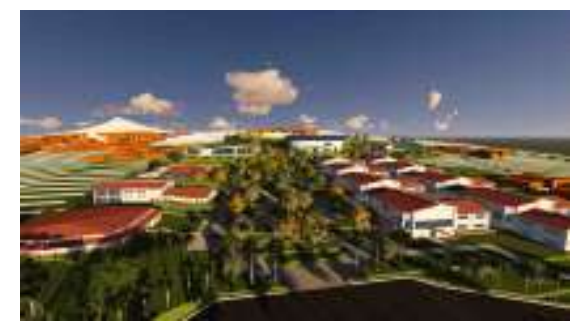

Gambar 10. Pusat Pelatihan Atlet Paralimpik

Desain bangunan pada Pusat Pelatihan Nasional dirancang untuk memenuhi prinsip Aksesibilitas Arsitektur (Gambar 11). Hal ini sebagai upaya untuk membantu atlet paralimpik dalam berlatih dan menggunakan fasilitas yang ada (Gambar 12).

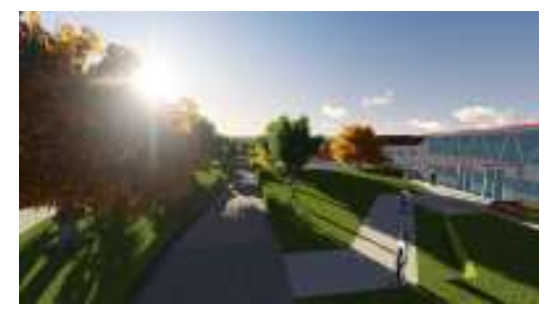

Gambar 11. Ram yang berada di lingkungan Pusat Pelatihan Nasional. 


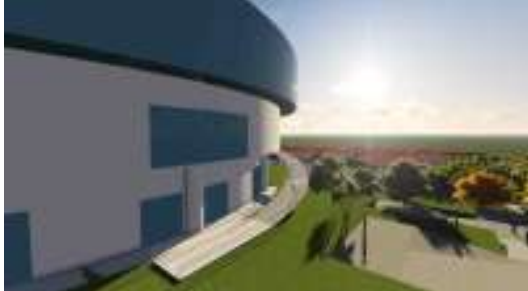

Gambar 12. Ram yang ada di bangunan sebagai sirkulasinya.

Perwujudan sarana dan prasarana olahraga yang berfungsi untuk meningkatkan kemampuan dari atlet paralimpik dibagi menjadi beberapa massa bangunan. Sarana tersebut dibagi menjadi 2 macam, yaitu olahraga indoor (Gambar 13 dan 14) dan olahraga outdoor (Gambar 15).

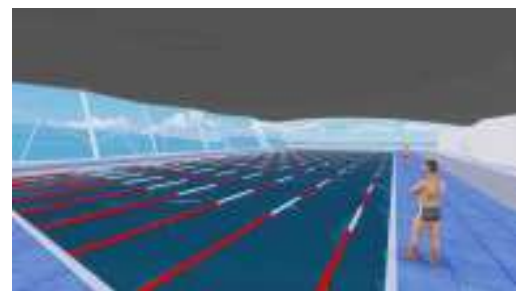

Gambar 13. Fasilitas Kolam Renang

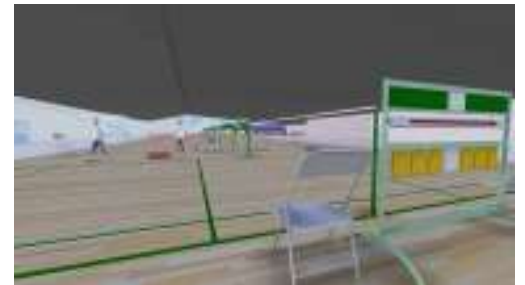

Gambar 14. Fasilitas Gedung Olahraga

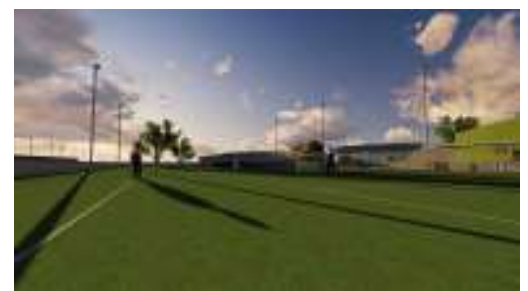

Gambar 15. Fasilitas Lapangan Tenis

Sedangkan sarana dan prasarana yang menunjang fasilitas olahraga juga dibagi menjadi beberapa massa bangunan (Gambar 16 dan 17). Hal ini dikarenakan bangunan tersebut merespon kontur alami pada tapak. Serta konsep pusat pelatihan yang menerapkan ram sebagai semua sirkulasi yang ada. Hal ini bertujuan untuk menyamakan semua pengguna dari Pusat Pelatihan Nasional.

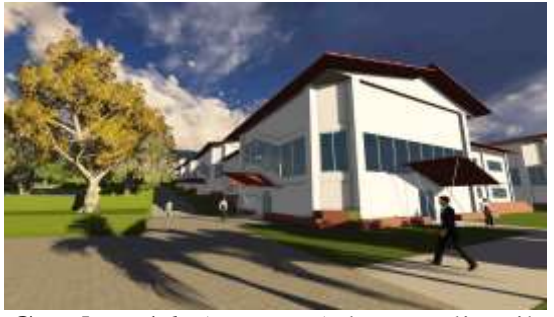

Gambar 16. Asrama Atlet Paralimpik

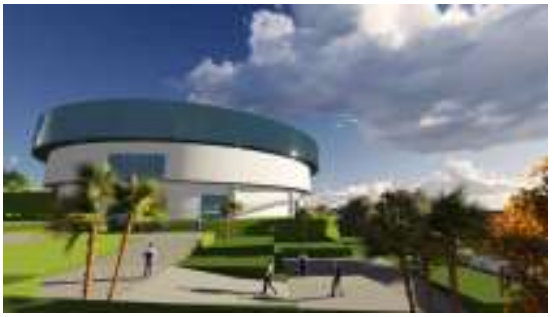

Gambar 17. Gedung Pameran

\section{REFERENSI}

Harsono. 2008,.Coaching dan Aspek-Aspek Psikologis dalam Coaching. Jakarta: CV Tambak Kusuma.

Wibowo, Basuki. 2002. Kamus Besar Bahasa Indonesia. Jakarta: Balai Pustaka.

Republik Indonesia. Peraturan Menteri Pekerjaan Umum Nomor 30/PRT/M/2006 Tentang Pedoman Teknis Fasilitas dan Aksesibilitas Pada Bangunan Gedung dan Lingkungan, ditetapkan pada tanggal 1 Desember 2006. 